\title{
Development of Volleyball Learning Media Based on E-Learning
}

\author{
Dewi Endriani ${ }^{1}$, Syamsul Gultom ${ }^{2}$, Yan Indra ${ }^{3}$ \\ \{ dewiendriani80@gmail.com ${ }^{1}$ \} \\ Department of Sports Sciences, Faculty of Sports Sciences, State Uiversity of Medan ${ }^{123}$
}

\begin{abstract}
This study aims at developing a Moodle-based e-learning system for teaching volleyball that will ease students and lecturers in Sport Science Faculty of UNIMED. The method employed in this study is research and development model. The population of this study is students of the Department of Sport Training \& Education. From the population, sample is drawn purposively with an inclusion criteria for students who take the Development of Technique and Tactics of Volley Ball class in the $5^{\text {th }}$ semester. The results showed that the development of e-learning applications in volleyball courses had reached the stage of media development, where in the development of this media a course description, lecture material, assessment and information column had been formed, so that from this development would be continued with product evaluation for see the effectiveness of the e-learning.
\end{abstract}

Keywords: Volleyball, E-Learning.

\section{Introduction}

Information and Communication Technology in the Learning Process is now a necessity, because with ICT it makes it easier for students to learn and obtain information from lecturers. Of course ICT can be one of the media in the learning process, in applying the media in this case e-learning must pay attention to the readiness of not only lecturers but also students. In order for students to learn smoothly and effectively, creativity is needed for a lecturer to design e-learning so as to motivate students to be active and creative in following the learning. The importance of ICT in strategic education in general and in particular, the great potential, to change the way in which teaching is carried out in class (Japhet E. Lawrence, Usman A Tar: 2018)

The e-learning based media that is used is using the moodle version application .... which is an application with operational language that is easy to use, the Sports coaching education department is one of the departments that apply the KKNI curriculum and obtain an A accreditation, therefore the output from PKO needs to be improved, in order to achieve a satisfactory graduates' competency standards, so we need a learning tools, in this case elearning based volleyball learning media. This study aims to design a volleyball-based learning media based on e-learning to facilitate students and lecturers in the learning process using the Moodle application in the FIK-Unimed PKO Department in volleyball courses. 


\section{Methods}

The research method that will be used in this research is research and development methods, namely research that is oriented to develop and validate media products. Research development or known as R \& D (Research and Development) according to Borg and Gall (1983: 772), states that research and development is a process / method used to develop and validate products. In this case the product developed is learning media in Volleyball lectures through E-Learning in Unimed FIK Sports Coaching Education Department students

This research was conducted in Unimed FIK Sports Coaching Education Department. especially in students who take the Volleyball Technical \& Tactic Development Course in $5^{\text {th }}$ semester.

The data analysis technique in this study is in the form of testing conducted by media experts (IT), material experts and students on the feasibility of products that have been developed in terms of aspects of appearance, programming. Learning and content or material data in the form of comments, suggestions for revisions and observations of researchers during the trial process were analyzed in qualitative descriptive, and concluded as input to improve or revise products that have been developed. Meanwhile, data in the form of response scores of media experts (IT), material experts and students obtained through questionnaires, were analyzed by quantitative descriptive with percentage techniques and categorization.

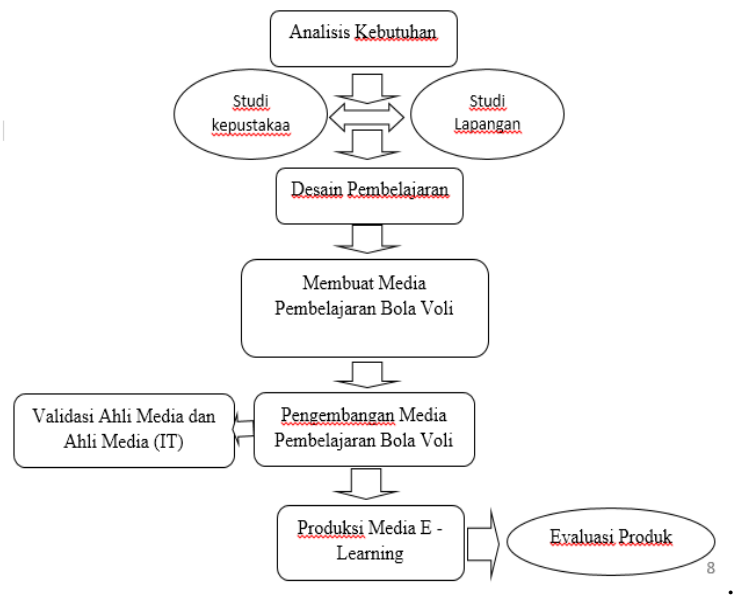

Figure 1: Steps for Research Development.

\section{Results and discussion}

This e-learning-based volleyball learning media has first analyzed the needs in the course, namely (1) the standard of graduate competence from the volleyball courses, (2) material based on basic competencies developed from the core competencies of each core competency, (3 ) assignments submitted by students in the form of soft files and videos, (4) assessments are designed in the form of written assessment (knowledge), portfolio (skills) and observations (attitudes) with a predetermined time limit. 
After the needs analysis was obtained, then the learning design was designed, in making the e-learning learning design researchers used the help of media experts (ICT) in the application design, both from the home display section (course description and SKL), material content display, and assignment display and assessment display.

Furthermore, researchers with lecturers on volleyball courses conducted Forum Group Discussions to produce material that was in accordance with SKL, then validated by two sports experts. And the next is that after this application is finished, two media experts (TIK) are validated again to see the use of this e-learning application, so that there are some shortcomings which will be further refined so that it can be used.
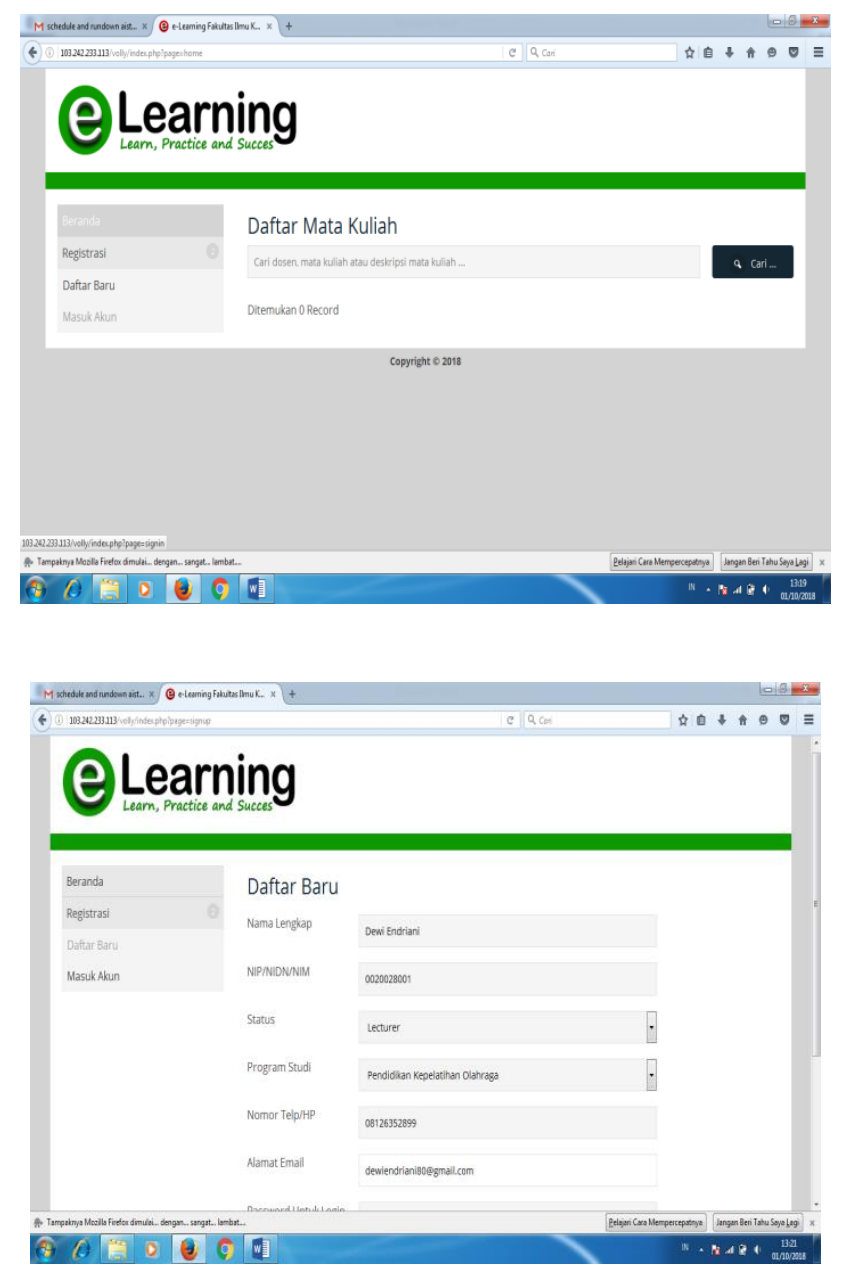


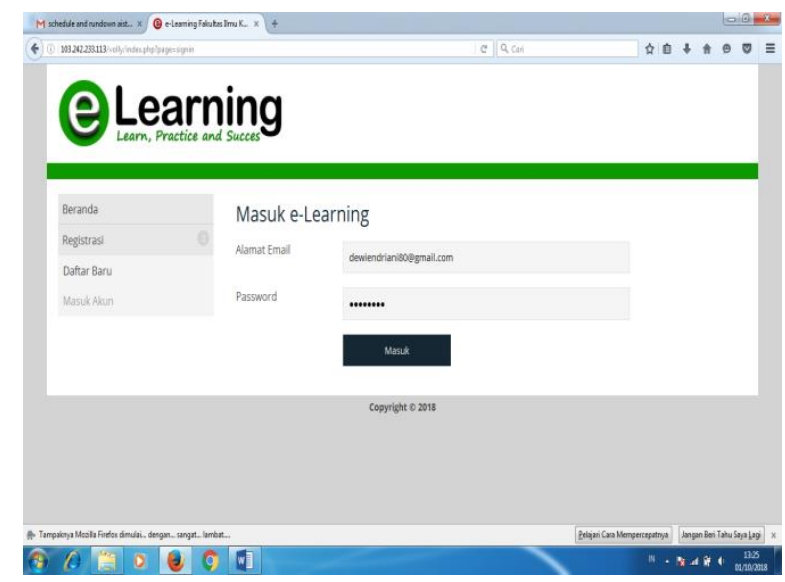

Figure 2. Shortcomings Examples 


\section{References}

[1] Arsyad Azwar.: Media Pembelajaran. Rajawali Press. ISBN : 978-979-769-513-2, Edisi Revisi Cetakan 2, (2013)

[2] Asnawir dan M. Basyaruddin Usman.: Media Pembelajaran. Ciputat Pers, Jakarta (2002)

[3] Bowles M.S.: Learning to E-Learning, (2004)

[4] Lawrence Japhet E.,Usman A Tar.: Factors that influence teachers' adoption and integration of ICT in teaching/learning process. $\mathrm{Pp},(2018)$

https://www.tandfonline.com/doi/full/10.1080/09523987.2018.1439712

[5] Marc J. Rosenberg.: strategies for delivering knowledge in the digital age. McGraw-Hill Companies, Inc, New York (2001)

[6]Motaz, A.: Start programming using Object Pascal. Vol. 2, pp. 10-11. Legally Free Computer Books, US (2013)

[7] Munir.: Pembelajaran Jarak Jauh Berbasis Teknologi Informasi Dan Komunikasi. pp. 171-172

[8] OECD Education Working Papers.: No. 45, OECD Publishing. Retrieved June 20, 2012, from http://dx.doi.org/10.1787/5kmhds6czqzq-en

[9] Oemar Hamalik.: Kurikulum dan Pembelajaran. Bumi Aksara, Jakarta (2003)

http://ahmadnurkholis19.blogspot.co.id/2012/12/pentingnya-media-dalam-pembelajaran pai.html

[10] Tay E Laine ., Matthew Allen.: Designing social media into university learning: technology of collaboration or collaboration for technology?,. pp. 151-163 (2011)

https://www.tandfonline.com/doi/full/10.1080/09523987.2011.607319

[11]Triono M. Brury.: The Indicators of Instructional Design.. Vol. 204, pp. 54-61. E- learning in Indonesian Vocational High Schools, (2015).

https://www.sciencedirect.com/science/article/pii/S1877042815047576 